\title{
The role of individual caspases in cell death induction by taxanes in breast cancer cells
}

\author{
Michael Jelínek', Kamila Balušíková', Martina Schmiedlová', Vlasta Němcová-Fürstová', Jan Šrámek', \\ Jitka Stančíková ${ }^{1}$, Ilaria Zanardi ${ }^{2}$ Iwao Ojima² and Jan Kovár ${ }^{*}$
}

\begin{abstract}
Background: In previous study we showed that caspase-2 plays the role of an apical caspase in cell death induction by taxanes in breast cancer cells. This study deals with the role of other caspases. We tested breast cancer cell lines SK-BR-3 (functional caspase-3) and MCF-7 (nonfunctional caspase-3).

Methods and results: Using western blot analysis we demonstrated the activation of initiator caspase- 8 and -9 as well as executioner caspase- 6 and -7 in both tested cell lines after application of taxanes (paclitaxel, SB-T-1216) at deathinducing concentrations. Caspase-3 activation was also found in SK-BR-3 cells. Employing specific siRNAs after taxane application, suppression of caspase-3 expression significantly increased the number of surviving SK-BR-3 cells. Inhibition of caspase-7 expression also increased the number of surviving SK-BR-3 and MCF-7 cells. On the other hand, suppression of caspase-8 and caspase-9 expression had no significant effect on cell survival. However, caspase-9 seemed to be involved in the activation of caspase-3 and caspase-7. Caspase-3 and caspase-7 appeared to activate mutually. Furthermore, we observed a significant decrease in mitochondrial membrane potential (flow cytometric analysis) and cytochrome $\mathrm{c}$ release (confocal microscopy, western blot after cell fractionation) from mitochondria in SK-BR-3 cells. No such changes were observed in MCF-7 cells after taxane treatment.

Conclusion: We conclude that the activation of apical caspase-2 results in the activation of caspase-3 and -7 without the involvement of mitochondria. Caspase- 9 can be activated directly via caspase-2 or alternatively after cytochrome c release from mitochondria. Subsequently, caspase- 9 activation can also lead to caspase-3 and -7 activations. Caspase-3 and caspase-7 activate mutually. It seems that there is also a parallel pathway involving mitochondria that can cooperate in taxane-induced cell death in breast cancer cells.
\end{abstract}

Keywords: Taxanes, Breast cancer, Caspases, Cell death

\section{Background}

Taxanes are known mitotic poisons. There are two taxanes currently used in cancer therapy, paclitaxel $\left(\mathrm{Taxol}^{\circ}\right)$ of natural origin and semi synthetic docetaxel (Taxotere ${ }^{\circ}$ ). They are routinely used in chemotherapy of solid tumors, e.g. breast cancer, ovary cancer, lung cancer and prostate cancer [1]. Unfortunately, resistance of cancer cells to clinically used taxanes (classical taxanes) became a problem. Novel taxanes have been developed in order to overcome resistance of cancer cells [2-4]. Some of these novel taxanes are significantly more effective in resistant cancer cells $[5,6]$.

\footnotetext{
* Correspondence: jan.kovar@lf3.cuni.cz

'Department of Cell and Molecular Biology, Third Faculty of Medicine,

Charles University, Prague, Czech Republic

Full list of author information is available at the end of the article
}

Taxanes bind to the $\beta$ subunit of the tubulin heterodimer and prevent depolymerization of microtubules. The stabilization of microtubules blocks progression through the $\mathrm{M}$ phase of the cell cycle $[7,8]$. This state of mitotic arrest normally results in cell death and it is supposedly associated with mitotic catastrophe, which has been observed by many authors in taxanes-treated cells [9-12]. Although there are numerous studies concerning taxaneinduced cell death in cancer cells, the molecular mechanism remains elusive [12-14].

It is well known, that functional caspases are required for completing apoptosis after various stimuli. Initiator caspase- $9,-8,-10,-2$ are involved in apoptosis induction and executioner caspase- $3,-6$ and -7 are involved in apoptosis execution. The activation of various caspases has been observed after taxane application in many types 
of cancer cells. The activation of initiator caspase-8, often associated with the death receptor signaling pathway, has been found in cells treated with taxanes $[15,16]$. In contrast, the role of caspase-8, apart from its involvement in certain amplification loops, has been seriously questioned, particularly in regard to melanoma cancer cells $[13,15]$. The activity of caspase-10, which, together with caspase-8, is involved in the extrinsic apoptotic pathway, has been observed in human leukemia cells after taxane application. However it was not associated with the activation of death receptors [17].

Caspase- 2 is a highly conservative protease and it is known to be involved in cell death induction by several different stimuli, e.g. heat shock, growth factors withdrawal or cytoskeleton damage [18]. It is often activated within a cytoplasmic complex, containing in addition PIDD protein and RAIDD protein, referred to as a PIDDosome [19]. Recently, several laboratories, including ours have reported that caspase- 2 appears to play a pivotal role in taxane-induced cell death [13,20,21].

Initiator caspase-9 is involved in the mitochondrial pathway of apoptosis induction and its activity has been found in several cancer cell lines [14,16,22] and also in non-cancer cells [23] after taxane application. It indicates that mitochondria can play an important role in the taxane-induced apoptosis at least in certain cancer cell lines $[9,24]$. Taxanes have also been found to induce the release of cytochrome $\mathrm{c}$ from isolated mitochondria [25] as well as from mitochondria in cancer cells [26,27] or embryonic cells [21]. The release of cytochrome $\mathrm{c}$ is a hallmark of apoptosis induction via the intrinsic apoptotic pathway. Another significant feature is decreasing mitochondrial membrane potential $\left(\Delta \psi_{\mathrm{m}}\right)$. Some studies in melanoma and prostate cancer cells have observed decreasing $\Delta \psi_{\mathrm{m}}$ after taxane treatment [13,28].

The activation of the key executive caspase-3 and/or cleavage of its substrate PARP have been observed in many cancer cell types after taxane application $[12,14,16]$. On the other hand, the role of caspase- 6 and -7 in cell death induction remains somewhat unclear $[17,29]$. However, activation of caspase- 7 has been detected in breast cancer cells after taxane exposure [30] as well as after combination treatments [31].

In our previous study, we described the activation of caspase-8, -9 and -3 in sensitive and resistant breast cancer cells after apoptosis induction by paclitaxel, the novel taxane SB-T-1216 as well as certain novel fluorinated taxanes. We observed that cytochrome $\mathrm{c}$ was released from the mitochondria in one of the tested cancer cell lines. We also showed that caspase- 2 was significantly involved in taxane-induced cell death in breast cancer cells $[5,12]$. Caspase- 2 affected the activation of caspase- $3,-7,-8$ and -9 . Thus caspase- 2 seemed to play the role of an apical caspase [20].
In the present study we tested the role of individual caspases in taxane-induced cell death in breast cancer cells. We tested two breast cancer cell lines, SK-BR-3 and MCF-7. It is known that functional p53 is absent in SK-BR-3 cells but present in MCF-7 cells. On the other hand, SK-BR-3 cells are known to have functional caspase-3 while MCF-7 cells are deficient in functional caspase-3 [32,33]. Such differences in proteins involved in apoptosis facilitated elucidation of the role of individual caspases in taxane-induced cell death. We found that the activation of apical caspase- 2 led to the activation of executioner caspase- 3 and -7 without the mitochondria involvement. Although a parallel pathway involving cytochrome $\mathrm{c}$ release and caspase- 9 activation may also be involved.

\section{Results}

Effect of taxanes on caspase-3 activation

In order to assess caspase-3 activation in SK-BR-3 cells after taxane application (MCF-7 cells have no functional caspase-3), we tested the time course of procaspase-3 cleavage using western blot analysis.

Procaspase-3 levels decreased significantly $36 \mathrm{~h}$ after application of both taxanes at death-inducing concentration (100 nM in SK-BR-3 cells, see "Materials and methods"). After $48 \mathrm{~h}$, the level of procaspase-3 in SKBR-3 cells was extremely low (data not shown). The decrease of procaspase- 3 levels correlated with dramatically increased levels of the cleaved form of caspase- 3 which occurred $36 \mathrm{~h}$ after taxane application. However, low levels of cleaved caspase- 3 were detectable $24 \mathrm{~h}$ after taxanes application (Figure 1A). The time course of caspase-3 activation is in agreement with our finding that most of SK-BR-3 cells are dead before 48 h of taxane treatment (our unpublished data).

Using western blot analysis, the time course of the levels of caspase- 3 substrate PARP was also assessed. A significant decrease in PARP levels after $36 \mathrm{~h}$ as well as significant increase in cleaved PARP levels after $24 \mathrm{~h}$ and $36 \mathrm{~h}$ corresponded with caspase- 3 activation after taxane application (Figure 1B). In MCF-7 cells, the cleavage of PARP was also detected $36 \mathrm{~h}$ after taxane application (data not shown).

\section{Effect of taxanes on caspase- 6 and -7 activations}

In order to assess the activation of other executioner caspases (caspase- 6 and -7) in both studied cell lines after taxane application, we tested the time course of procaspase- 6 and -7 cleavage using western blot analysis.

Procaspase- 6 levels decreased somewhat $36 \mathrm{~h}$ after the application of taxanes at death-inducing concentration (100 nM) in SK-BR-3 cells. Some decrease was also seen $24 \mathrm{~h}$ after the application. Concerning MCF-7 cells, similar effect was seen at least $60 \mathrm{~h}$ after taxane 


\section{SK-BR-3}

A

Paclitaxel
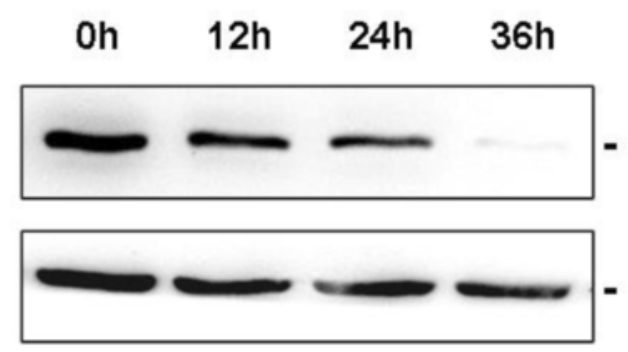

Oh $12 \mathrm{~h}$

24h

$36 \mathrm{~h}$
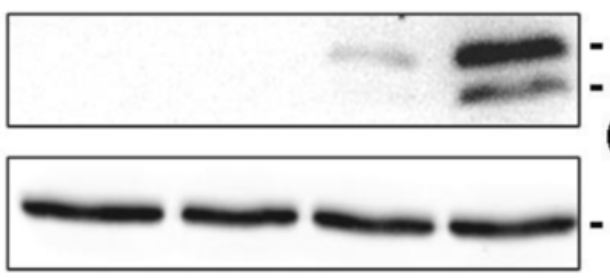

SB-T-1216

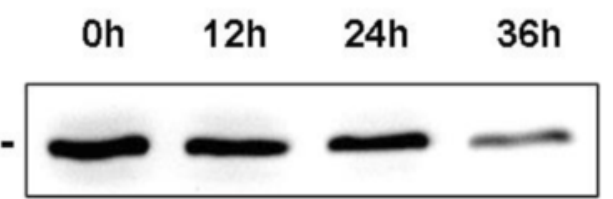

Actin

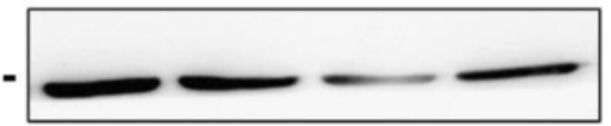

Oh

$12 \mathrm{~h} \quad 24 \mathrm{~h}$

$36 \mathrm{~h}$

B

\section{Paclitaxel}

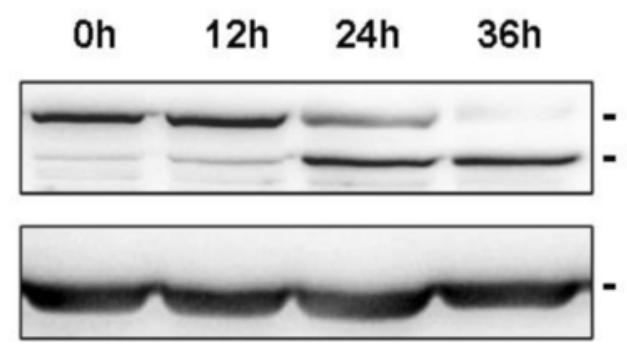

Actin Cleaved
caspase-3
(19 kD and $17 \mathrm{kD})$

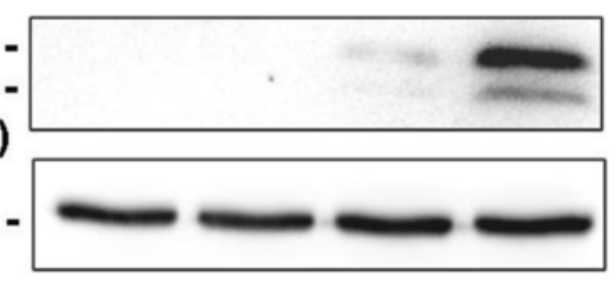

\section{SB-T-1216}

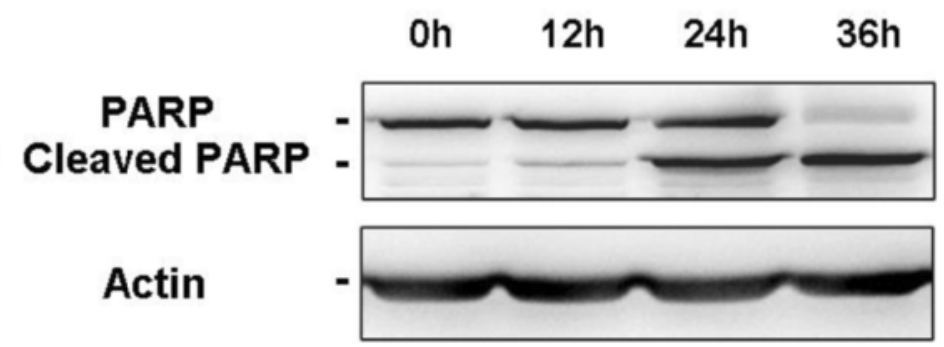

Figure 1 Effect of paclitaxel and SB-T-1216 on the activation and activity of caspase-3 in SK-BR-3 cells. After 0, 12,24 and 36 h of incubation with paclitaxel or SB-T-1216 (100 nM), levels of (A) procaspase-3 and cleaved caspase-3 as well as (B) levels of PARP were determined using western blot analysis and relevant antibodies (see "Materials an methods"). Actin levels were used to confirm equal protein loading. The data shown were obtained in one representative experiment of two independent experiments.

application at death inducing concentration (300 $\mathrm{nM}$ in MCF-7 cells, see "Materials and methods"). The decrease of procaspase-6 levels in SK-BR-3 cells correlated roughly with increased levels of the cleaved form of caspase-6 $24 \mathrm{~h}$ and $36 \mathrm{~h}$ after taxanes application. In MCF-7 cells, cleaved caspase- 6 was seen from 36 h to $60 \mathrm{~h}$ after application (Figure 2A).

Procaspase-7 levels decreased slightly $36 \mathrm{~h}$ after taxane application in SK-BR-3 cells. In MCF-7 cells, there was also certain decrease in procaspase-7 level $60 \mathrm{~h}$ after taxane application. Increased levels of the cleaved form of caspase- 7 were detected $24 \mathrm{~h}$ and particularly $36 \mathrm{~h}$ after taxane application in SK-BR-3 cells and from $24 \mathrm{~h}$ to
$48 \mathrm{~h}$ or even $60 \mathrm{~h}$ in MCF-7 cells (Figure 2B). The time course of caspase- 6 and -7 activations is also in agreement with our finding that most of cells are dead before $48 \mathrm{~h}$ of taxane treatment (our unpublished data).

Effect of taxanes on caspase- 8 and -9 activations

Using western blot analysis, we assessed the activation of initiator caspase- 8 and -9 after taxane application by testing the time course of procaspase- 8 and -9 cleavages.

Procaspase- 8 levels decreased $36 \mathrm{~h}$ after the application of both taxanes at death-inducing concentration (100 nM) in SK-BR-3 cells. Concerning MCF-7 cells, a decrease in procaspase- 8 levels after the application of 


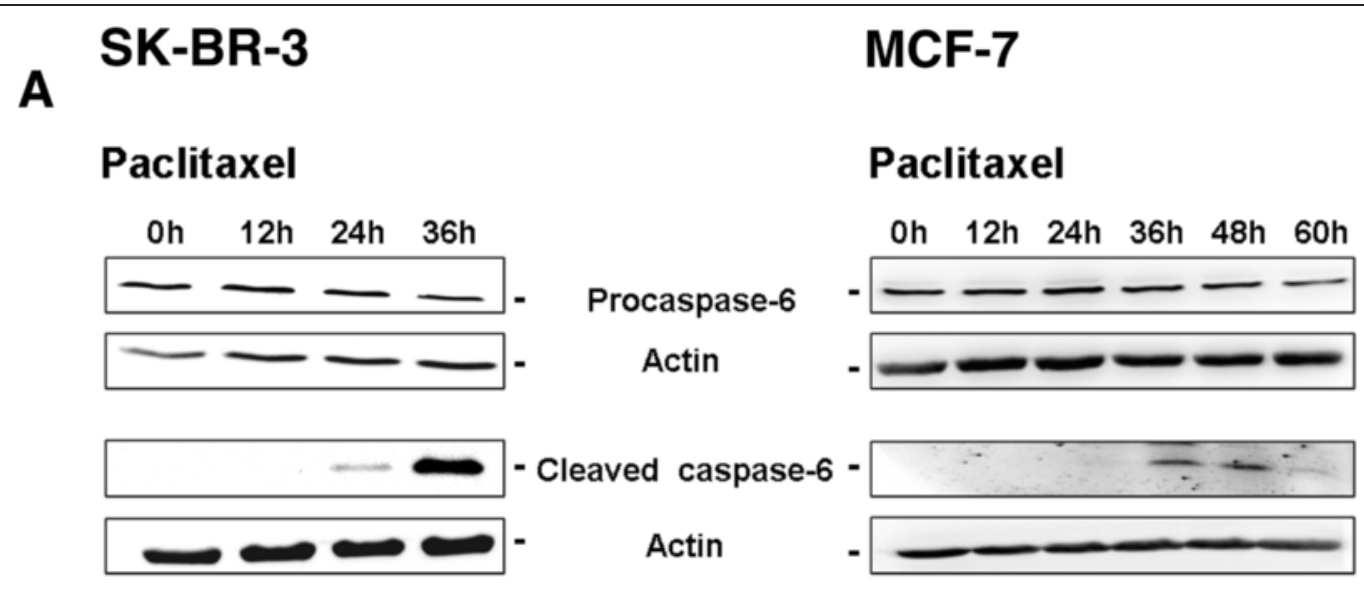

SB-T-1216

\section{SB-T-1216}
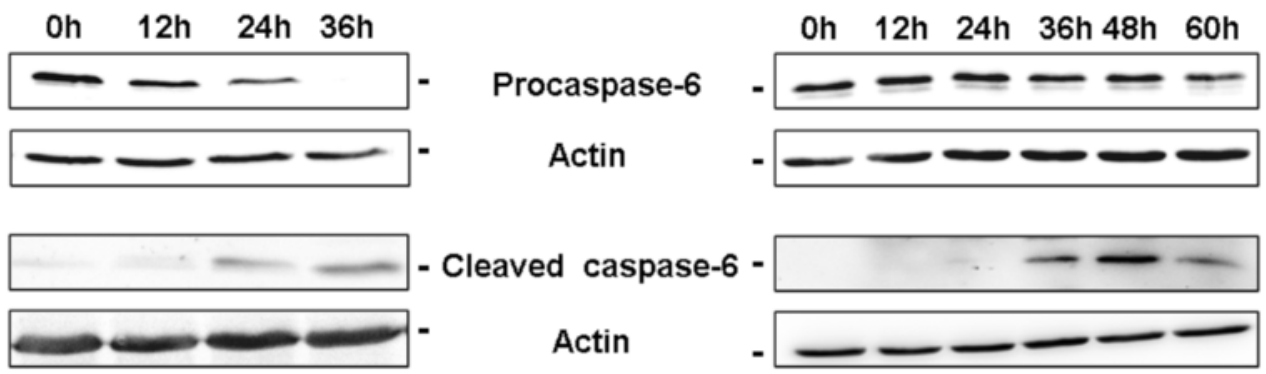

B

\section{Paclitaxel}

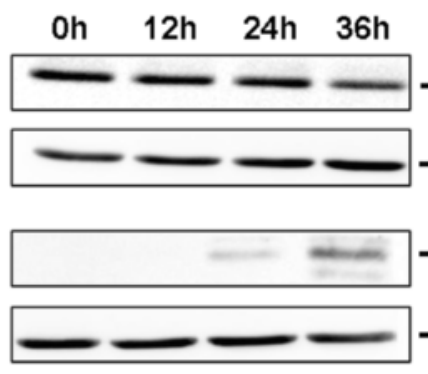

SB-T-1216
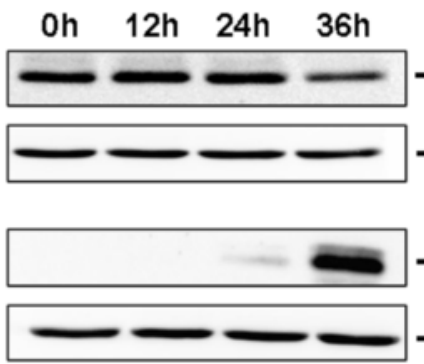

\section{Paclitaxel}

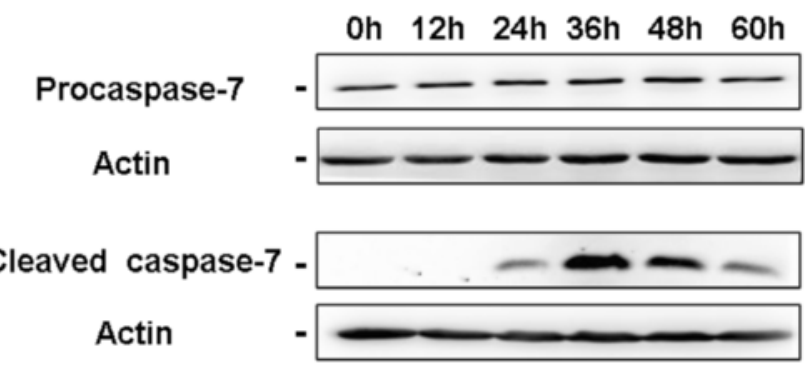

SB-T-1216

Figure 2 (See legend on next page.) 
(See figure on previous page.)

Figure 2 Effect of paclitaxel and SB-T-1216 on (A) the activation of caspase-6 and (B) the activation of caspase-7 in SK-BR-3 and MCF-7 cells. After $0,12,24,36,48$ and 60 h of incubation with paclitaxel or SB-T-1216 (100 nM for SK-BR-3 cells and 300 nM for MCF-7 cells), levels of procaspases and cleaved caspases were determined using western blot analysis and relevant antibodies (see "Materials and methods"). Actin levels were used to confirm equal protein loading. The data shown were obtained in one representative experiment of two independent experiments.

taxanes at death-inducing concentration (300 nM) was not detected. The decrease of procaspase- 8 levels in SKBR-3 cells correlated with increased levels of the cleaved form of caspase-8 $36 \mathrm{~h}$ after taxanes application. Cleaved caspase- 8 was seen in MCF-7 cells from $24 \mathrm{~h}$ to $60 \mathrm{~h}$ after taxane application, in spite of the fact that the cleavage of procaspase- 8 was not detected here (Figure $3 \mathrm{~A}$ ).

Regarding caspase-9, the decrease of procaspase- 9 levels after taxane application was not clearly detected in SK-BR-3 or MCF-7 cells. Increased levels of the cleaved form of caspase- 9 appeared $24 \mathrm{~h}$ after taxanes application in SK-BR-3 cells. The increase was more pronounced $36 \mathrm{~h}$ after the application. Cleaved caspase- 9 levels were also seen from $24 \mathrm{~h}$ to $60 \mathrm{~h}$ after taxane application in MCF-7 cells (Figure 3B). Similarly like in the case of caspase-3, -6 and -7 , the time course of caspase8 and -9 activations is in agreement with our finding that cells are principally dead before $48 \mathrm{~h}$ of taxane treatment (our unpublished data).

\section{Effect of the inhibition of caspase-3, $-7,-8$ and -9 expression on taxane induced cell death}

Employing RNA interference, we assessed the effect of specific inhibition of caspase- $3,-7,-8$ and -9 expressions on cell death induction by taxane application.

First, the efficiency of the RNA interference was tested. It revealed that inhibition of the expression of individual caspases was efficient enough in both SK-BR-3 and MCF-7 cells (Figure 4A). Furthermore, nonsense siRNA or specific caspase siRNAs did not significantly affect cell growth or survival in either cell line. Cell transfected with siRNAs seemed to grow slightly slower when compared with control cells (data not shown). In spite of this fact, in the case of caspase- 3 and -7 we were able to detect significant increase of cell growth and survival after the inhibition of caspase expression by siRNA application when cells were incubated with taxanes (see below).

After $48 \mathrm{~h}$ of incubation with taxanes at deathinducing concentrations (100 $\mathrm{nM}$ ), inhibition of caspase3 expression (81\%) resulted in an approximately 6-fold increase in the number of surviving SK-BR-3 cells. For both taxanes, it represents a statistically significant increase from about $2 \%$ to $12-14 \%$ of the number of cells cultured without taxane. The inhibition of caspase-7 expression (81\%) resulted in an approximately 4-fold increase in the number of surviving SK-BR-3 cells after $48 \mathrm{~h}$ of incubation. It again represents a statistically significant increase (from about $2 \%$ to $7-8 \%$ ). After $96 \mathrm{~h}$, the effect of the inhibition of caspase- 3 and caspase-7 expression was similar or even more pronounced. On the other hand, we did not detect any significant effect of caspase-8 (94\%) or caspase-9 (70\%) suppression on cell death induction by taxanes in SK-BR-3 cells (Figure 4B).

Concerning MCF-7 cells, inhibition of caspase-7 expression $(81 \%)$ increased the number of surviving cells by approximately 2 -fold after 48 -h incubation with taxanes at death-inducing concentration (300 nM). It was a statistically significant increase from about $20 \%$ to about $40 \%$ of the number of cells cultured without taxane. After $96 \mathrm{~h}$, the effect of the inhibition of caspase-7 expression was very similar. We did not detect a significant effect of caspase-8 (89\%) and caspase-9 (61\%) suppression on taxane-induced cell death in MCF-7 cells. Perhaps there was a slight, although insignificant, increase of the number of surviving cells linked to the inhibition of caspase- 9 expression (Figure 4B).

Effect of the inhibition of caspase-8, $-9,-3$ and -7 expression on taxane induced activation of caspase- $8,-9,-3,-7$

Using the siRNA technique, we assessed the effect of specific inhibition of caspase- $3,-7,-8$ and -9 expression on the activation of caspase- $8,-9,-3$, and -7 after taxane application. Inhibition efficiency of individual caspases is mentioned above (or see "Materials and methods"). To confirm caspase- 2 role as an apical caspase [20], the effect of specific inhibition of the expression of tested caspases on procaspase-2 cleavage was also assessed after taxane application. No significant effect was found (Figure 5).

After 36-h incubation of SK-BR-3 cells with taxanes at death inducing concentration (100 nM), subsequent western blot analysis showed significantly decreased cleavage of caspase- $8,-9$ and -7 due to inhibition of caspase-3 expression. Decreased cleavage of caspase-3 was observed in response to inhibition of caspase-7 expression. Decreased cleavage of caspase- 9 was seen in response to inhibition of caspase- 8 expression and decreased cleavage of caspase- 3 and -7 linked to inhibition of caspase- 9 expression (Figure 5A).

Concerning MCF-7 cells after $36 \mathrm{~h}$ of incubation with taxanes at death-inducing concentration (300 nM), inhibition of caspase-7 expression did not significantly affect the cleavage of caspase- 9 but it slightly affected the cleavage of caspase-8. Inhibition of caspase-8 expression did not affect the cleavage of caspase- 9 and -7 . 


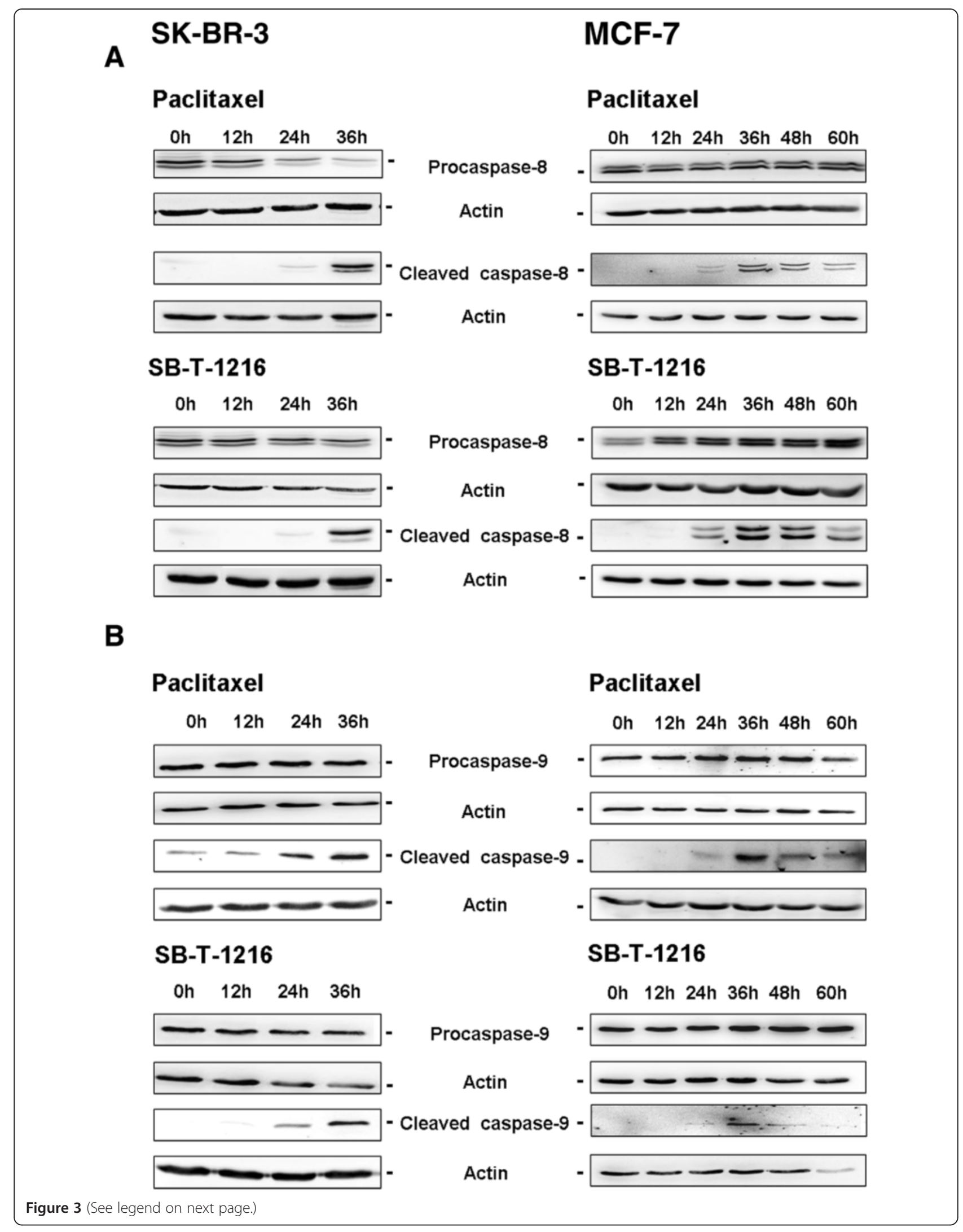


(See figure on previous page.)

Figure 3 Effect of paclitaxel and SB-T-1216 on (A) the activation of caspase-8 and (B) the activation of caspase-9 in SK-BR-3 and MCF-7 cells. After $0,12,24,36,48$ and $60 \mathrm{~h}$ of incubation with paclitaxel or SB-T-1216 (100 nM for SK-BR-3 cells and $300 \mathrm{nM}$ for MCF-7 cells), levels of procaspases and cleaved caspases were determined using western blot analysis and relevant antibodies (see "Materials and methods"). Actin levels were used to confirm equal protein loading. The data shown were obtained in one representative experiment of two independent experiments.

Inhibition of caspase- 9 expression did not affect the cleavage of caspase-8, but it significantly decreased the cleavage of caspase-7 (Figure 5B).

\section{Effect of taxanes on mitochondrial membrane potential}

$\left(\Delta \psi_{\mathrm{m}}\right)$

We employed [DiOC6(3)] staining and subsequent flow cytometry to assess the effect of taxanes on mitochondrial membrane potential $\left(\Delta \psi_{\mathrm{m}}\right)$.

In SK-BR-3 cells, within $36 \mathrm{~h}$ of incubation with taxanes at death-inducing concentration (100 nM), $\Delta \psi_{\mathrm{m}}$ decreased significantly close to a total collapse. On the other hand, $\Delta \psi_{\mathrm{m}}$ did not show any significant decrease in MCF-7 during $60 \mathrm{~h}$ after taxane application. It clearly demonstrated different responses of mitochondrial membrane potential to taxane application in SK-BR-3 and MCF-7 cells (Figure 6).

\section{Effect of taxanes on cytochrome c release}

The effect of tested taxanes on cytochrome c release from mitochondria was assessed using confocal microscopy and cell fractionation followed by western blot analysis.

Confocal microscopy showed that cytochrome c was mainly localized in the mitochondria of control SK-BR-3 as well as MCF-7 cells. After $36 \mathrm{~h}$ of incubation of SKBR-3 cells with taxanes at death-inducing concentration (100 nM), cytochrome c was released from the mitochondria into the cytosol. However, in MCF-7 cells, cytochrome c was still found within mitochondria $36 \mathrm{~h}$ after taxane application (300 nM) (Figure 7A).

These results were confirmed using western blot analysis after cell fractionation. Cytochrome c was shown to be mainly localized in the mitochondrial cell fraction in both SK-BR-3 and MCF-7 cells before taxane application. In SK-BR-3 cells, cytochrome c levels increased rapidly in the cytosolic fraction $24 \mathrm{~h}$ and particularly $36 \mathrm{~h}$ after taxane application. In MCF-7 cells, cytochrome c stayed mainly in the mitochondrial fraction after taxane application. Thus, after taxane application, cytochrome $\mathrm{c}$ is released from mitochondria only in SKBR-3 cells, but not in MCF-7 cells (Figure 7B).

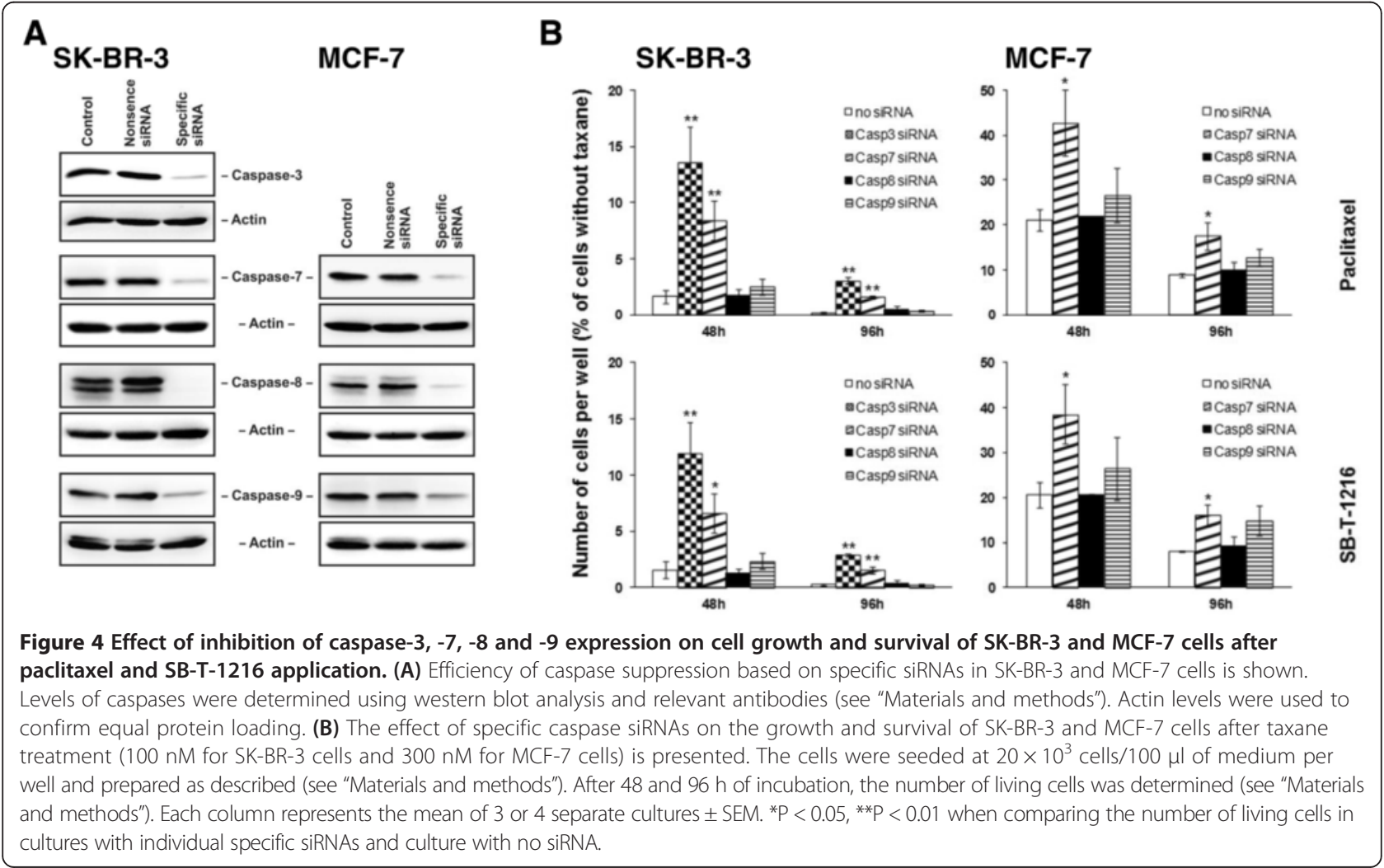


A

SK-BR-3

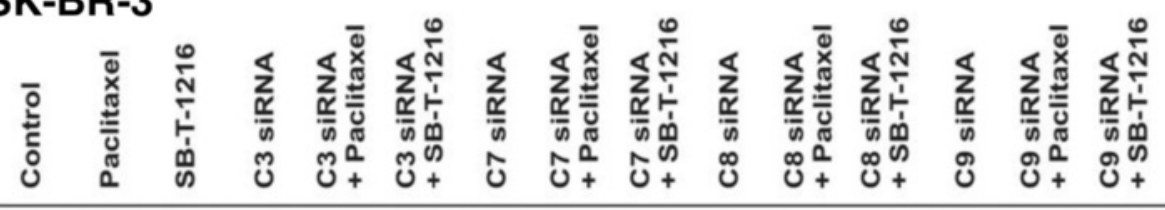
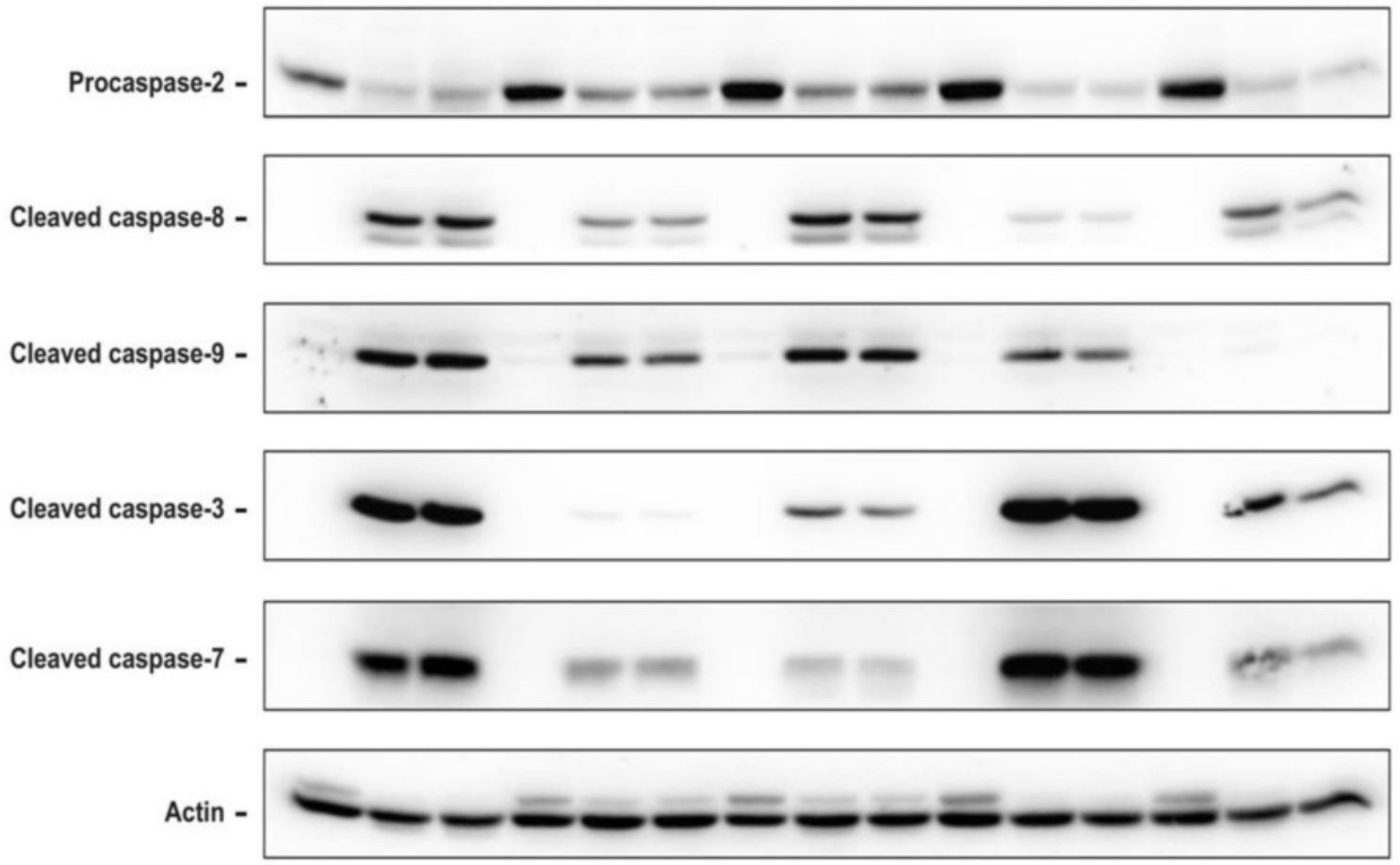

B

\section{MCF-7}

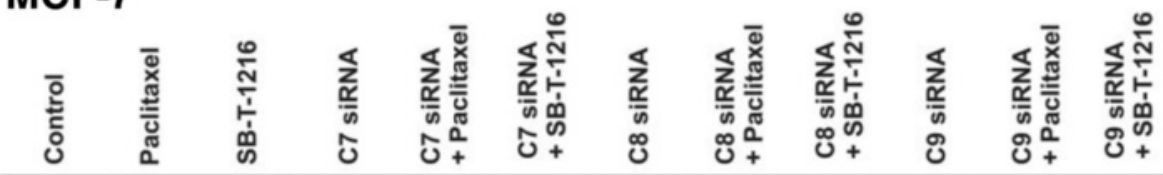

Procaspase-2 -
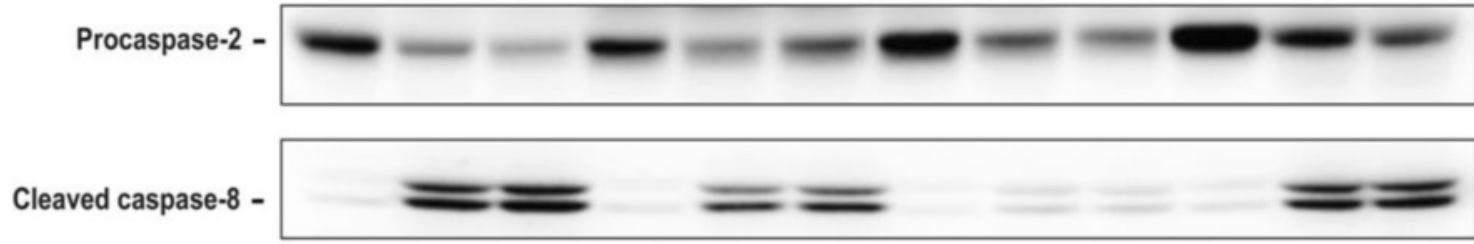

Cleaved caspase-9 -
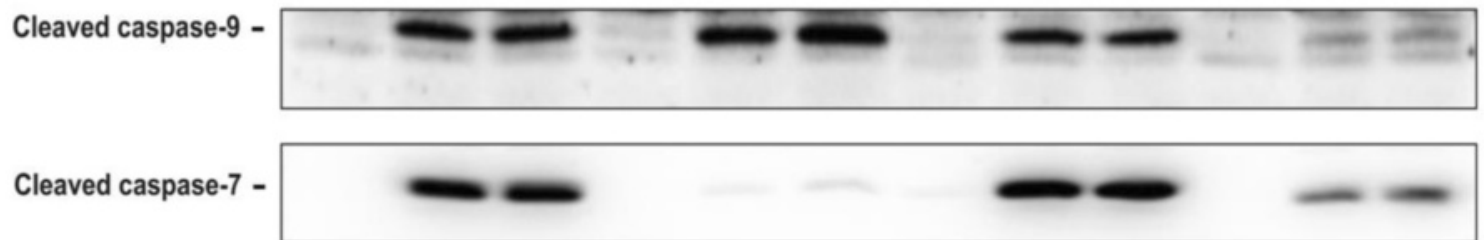

Actin -

Figure 5 (See legend on next page.) 
(See figure on previous page.)

Figure 5 Effect of the inhibition of caspase-3, $-7,-8$ and -9 expression on the activation of caspase-3, $-7,-8$ and -9 in (A) SK-BR-3 and (B) MCF-7 cells after paclitaxel and SB-T-1216 application. Specific caspase-3 siRNA, caspase-7 siRNA, caspase-8 siRNA and caspase-9 siRNA were used. Control cells were incubated without taxane and siRNA. After $36 \mathrm{~h}$ of incubation with the tested taxane (100 nM for SK-BR-3 cells and $300 \mathrm{nM}$ for MCF-7 cells) and relevant specific siRNA, levels of cleaved caspases were determined using western blot analysis and relevant antibodies (see "Materials and methods"). Actin levels were used to confirm equal protein loading. The data shown were obtained in one representative experiment of two independent experiments.

\section{SK-BR-3}

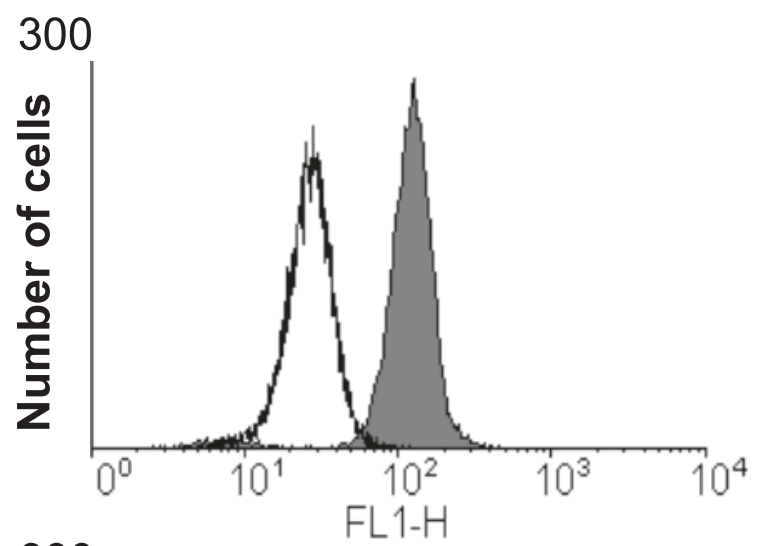

300

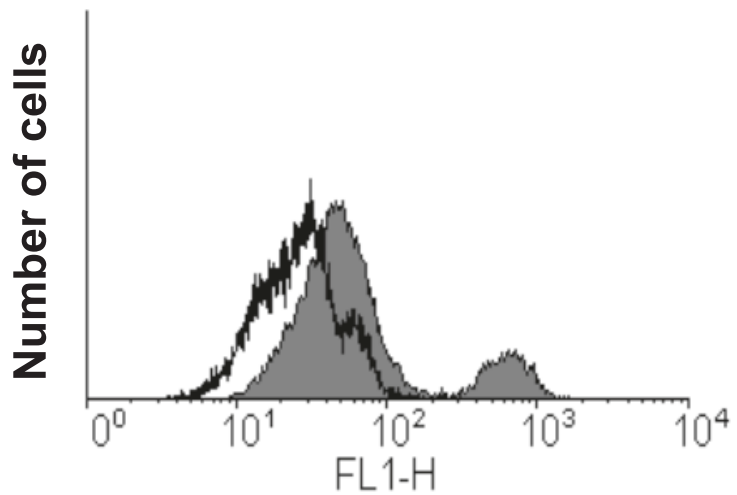

300

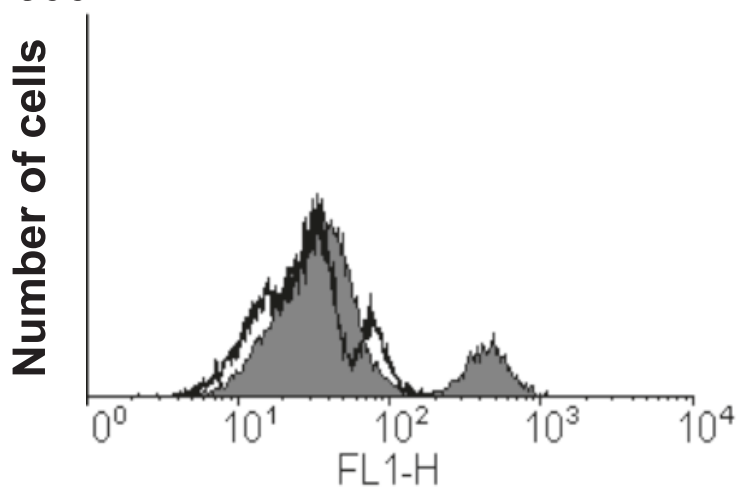

\section{MCF-7}

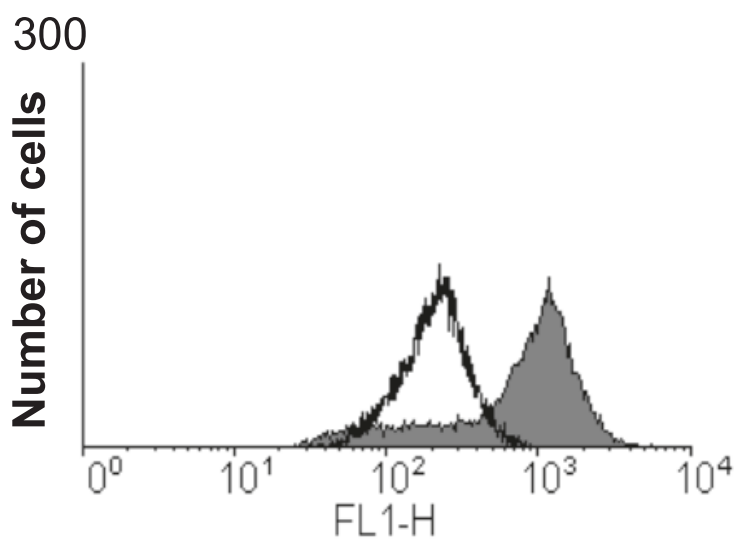

\section{0}

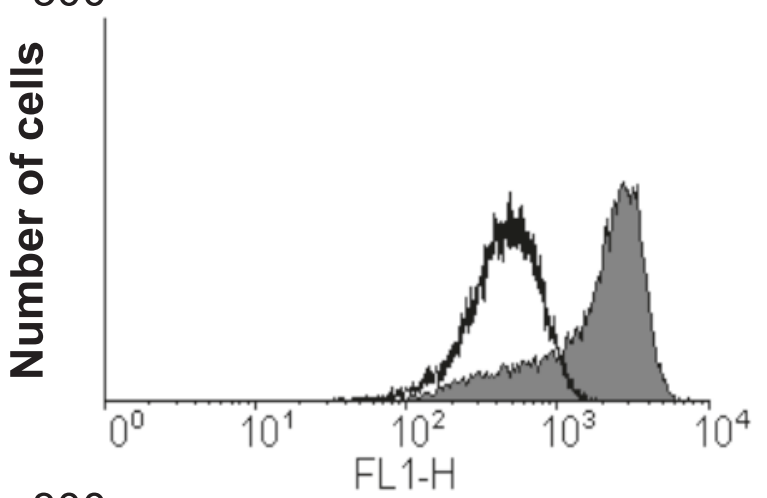

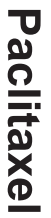

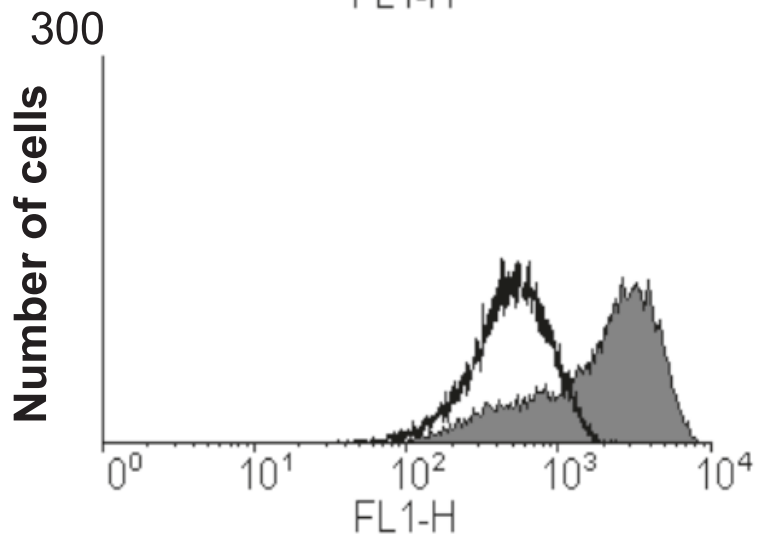

Figure 6 Effect of paclitaxel and SB-T-1216 on the mitochondrial membrane potential $\left(\Delta \Psi_{\mathrm{m}}\right)$ in SK-BR-3 and MCF-7 cells. Control cells were incubated without taxane. After $36 \mathrm{~h}$ (SK-BR-3) or $60 \mathrm{~h}$ (MCF-7) of incubation with tested taxane (100 nM for SK-BR-3 and 300 nM for MCF-7) the mitochondrial membrane potential was assessed using flow cytometry analysis of cells after staining with [DiOC6(3)] (see "Materials and methods"). The collapse of $\Delta \psi_{\mathrm{m}}$ caused by the application of CCCP is shown (blank areas). The data shown were obtained in one representative experiment of three independent experiments. 


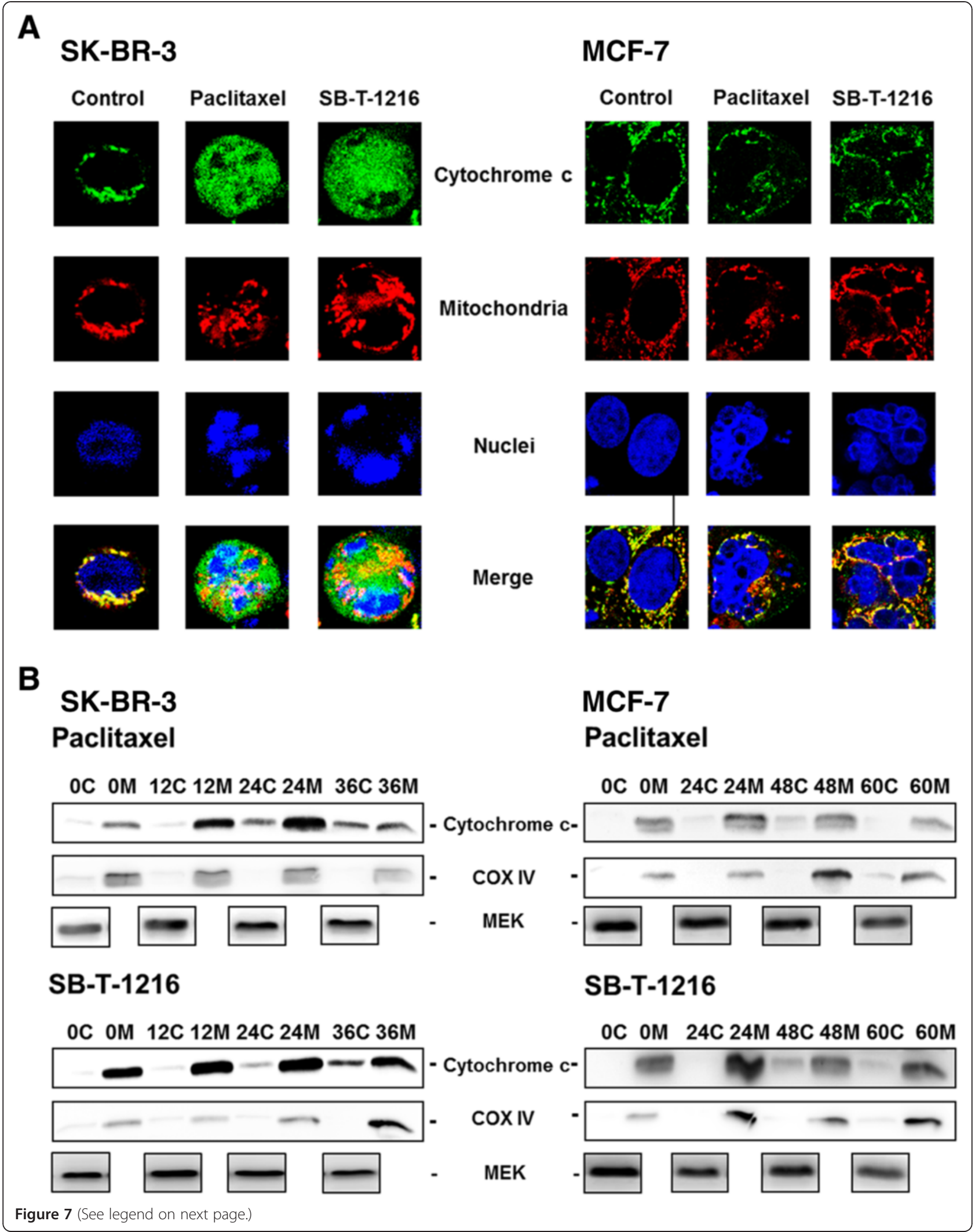


(See figure on previous page.)

Figure 7 Effect of paclitaxel and SB-T-1216 on cytochrome c release from mitochondria in SK-BR-3 and MCF-7 cells. (A) After $36 \mathrm{~h}$ of incubation with tested taxane (100 nM for SK-BR-3 cells and $300 \mathrm{nM}$ for MCF-7 cells), the localization of cytochrome c within the cells was detected using confocal microscopy (see "Materials and methods"). Control cells were incubated without taxane. The localization of cytochrome c (green), mitochondria (red), nuclei (blue) and the merge of cytochrome c, mitochondria and nuclei are shown. The data shown were obtained in one representative experiment of three independent experiments. (B) After 0, 12, 24, 36, 48 and $60 \mathrm{~h}$ of incubation with tested taxane (100 nM for SK-BR-3 cells and $300 \mathrm{nM}$ for MCF-7 cells), levels of cytochrome c in mitochondrial (M) and cytosolic (C) fractions were determined using western blot analysis and relevant antibodies (see "Materials and methods"). COX IV (integral mitochondrial protein) level was used to confirm proper fractionation. MEK levels were used to confirm equal protein loading of cytosolic fraction. The data shown were obtained in one representative experiment of three independent experiments.

\section{Discussion}

In our previous paper [20] we studied the role of caspase- 2 in taxane-induced cell death in breast cancer cells. It was suggested that caspase- 2 plays the role of an apical caspase. This study deals with the role of other caspases, i.e. initiator caspase- 8 and -9 as well as executioner caspase- 3 and -7 in taxane-induced cell death in breast cancer cells. The relationship between activation of individual caspases was of particular interest. We used two breast cancer cell lines, SK-BR-3 (nonfunctional p53, functional caspase-3) and MCF-7 (functional p53, nonfunctional caspase-3) as an experimental model. We previously reported that p53 is activated in MCF-7 cells after taxane application. However, we did not observed p53-induced increased expression of PIDD protein or any other function of p53 in activation of caspase- 2 that plays important role in cell death induction [20]. The role of p53 in apoptosis induction after taxane application is also questioned because we did not find the activation of mitochondrial death pathway to have a decisive role in cell death induction here. Importantly, apoptosis was induced in both tested cell lines even SK-BR-3 have no functional p53 [20]. Taken together, we do not suppose p53 to play an important role in cell death induction after taxane application in tested breast cancer cells.

We tested two taxanes, classical (clinically used) paclitaxel and novel taxane SB-T-1216. The effect of both taxanes was found to be very similar.

We found that caspase- 8 was activated after taxane application at death-inducing concentrations in both tested cell lines (see Figure 3). However, the suppression of caspase-8 expression did not affect cell survival after taxane treatment at all (see Figure 4). Activation of other caspases, especially the executioner caspases, was not significantly affected in cells where caspase- 8 expression had been inhibited (see Figure 5 ). The role of caspase- 8 in various types of cancer cells after taxane treatment has been previously discussed in several reports $[12,15]$. Interestingly, caspase- 8 activation was usually observed only with the simultaneous activation of other initiator caspases (caspase-2 and caspase-9) after taxane application $[12,16,22]$. The role of caspase- 8 in taxaneinduced cell death was questioned by Park et al. [17]. They did not find any significant role of caspase- 8 in taxane-induced cell death in lymphoid cells. Similarly, we suggest that caspase- 8 does not play any significant role in cell death induction by taxanes in breast cancer cells.

On the contrary, caspase- 2 seems to play a key role in cell death induction by taxanes [20]. We and others have shown that cancer as well as non-cancer cells without functional caspase-2 were more resistant to taxanes $[13,20,21]$. We showed that the inhibition of caspase-2 expression resulted in decreased activation of caspase-9, -3 and -7 after taxane application in breast cancer cells which implies that caspase-2 plays the role of an apical caspase in these cells [20] (see Figure 8).

Taxanes have been shown to induce the mitochondrial pathway of apoptosis induction by several authors $[5,9,23]$. Also in this study, we observed significant decreases of $\Delta \psi_{\mathrm{m}}$ and cytochrome c release from mitochondria in SK-BR-3 cells after taxane application. However, we did not detect any change in $\Delta \psi_{\mathrm{m}}$ or cytochrome c release in taxane-treated MCF-7 cells (see Figures 6 and 7). Previous reports have shown that cytochrome c was released from mitochondria and $\Delta \psi_{\mathrm{m}}$ decreased in certain types of cancer cells treated with taxane [5,27]. On the other hand, other types of cancer cells underwent cell death without cytochrome c release from mitochondria [5]. Recently, the role of cytochrome $\mathrm{c}$ in taxane-induced cell death was also assessed by Li et al. [34]. They observed cytochrome c release from mitochondria but cell death was induced without cytochrome $\mathrm{c}$ involvement. Thus, it seems that the mitochondrial pathway does not play an essential role in apoptosis induction by taxanes, at least in certain types of cancer cells (see Figure 8).

Caspase-9 was activated in SK-BR-3 cells and a relatively low degree of activation was also found in MCF-7 cells (see Figure 3). Activation of caspase-9 has been observed by many authors in various types of cancer cells after taxane treatment and it usually appeared together with caspase-3 activation [12,16,35]. Concerning the mechanism of caspase- 9 activation following taxane treatment, we suggest that there are at least two pathways involved. Caspase- 9 can be activated in the cytosol via the classical pathway after cytochrome c release from mitochondria or it can be activated via caspase-2 


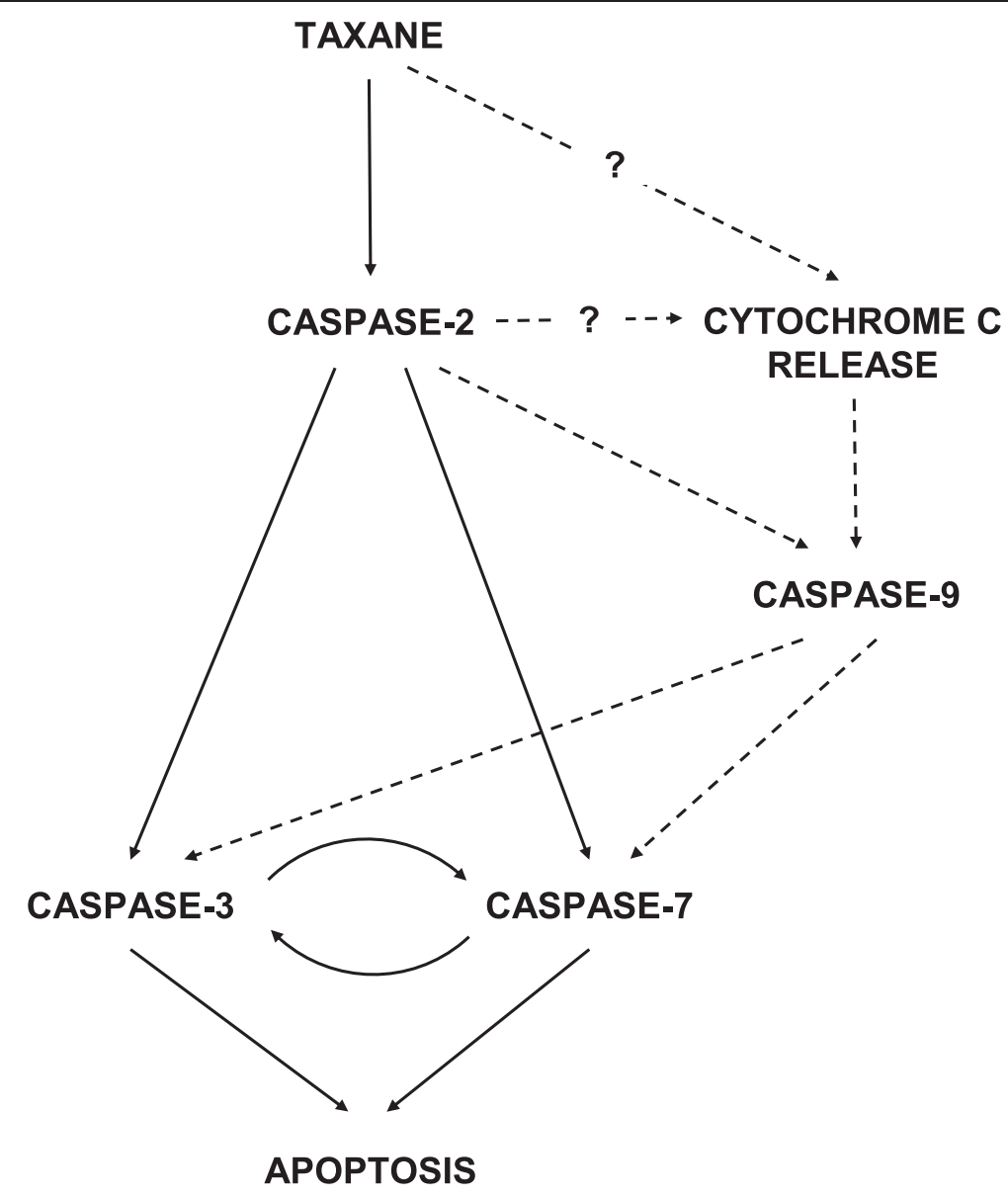

Figure 8 Scheme showing suggested pathways leading to the activation of individual caspases during apoptosis induction by taxanes in breast cancer cells. Solid lines represent the main pathway of apoptosis induction and dashed lines represent parallel pathways.

activation without the involvement of cytochrome c (see Figure 8). Although cells were slightly protected against cell death induction by the inhibition of caspase- 9 expression, the effect on cell survival after taxane application was not significant in both tested cell lines (see Figure 4). Independence of cell death induction by taxanes in MCF-7 cells on caspase-9 activity was described previously [36]. Using caspase-9 siRNA, we also found some decreased activation of executioner caspase- 3 and -7 after taxane application (see Figure 5). Finally, we suggest that caspase- 9 could play a role in the parallel pathway of executioner caspase- 3 and -7 activations after taxane application (see Figure 8).

Caspase-3 was activated and its substrate PARP was cleaved in SK-BR-3 cells after taxane application (see Figure 1). Caspase-3 was also found to be activated in other cancer cell types after exposure to paclitaxel $[16,24,37]$ or docetaxel [38]. Inhibition of caspase-3 expression increased the number of surviving SK-BR-3 cells significantly (see Figure 4). Concerning MCF-7 cells, there are previous reports demonstrating that overexpression of caspase-3, after transfection of the caspase-3 gene, increased the sensitivity of cells to paclitaxel [32]. On the other hand, caspase-3-independent cell death has been also reported to occur in MCF-7 cells transfected by the caspase-3 gene after paclitaxel application [36]. We also demonstrated that the suppression of caspase-3 expression decreased the activation of caspase-7 (see Figure 5). It confirms that caspase-7 is a caspase-3-activated caspase. Thus, caspase- 3 seems to be a universally important executioner caspase for taxaneinduced cell death in a variety of cancer cell types.

Executioner caspase- 7 and caspase- 6 were activated in tested cell lines after taxane application (see Figure 2). Caspase-7 activation was also observed during cell death induction by zoledronic acid in breast cancer cells [39] or in other types of cancer cells after paclitaxel application $[24,30]$. We showed that the suppression of caspase-7 expression significantly increased the number of surviving SK-BR-3 as well as MCF-7 cells (see Figure 4). MCF-7 cells without functional caspase-7 have been recently described to be more resistant to paclitaxel 
[40]. We also demonstrated that the inhibition of caspase-7 expression led to a decrease of caspase-3 activation in SK-BR-3 cells (see Figure 5). Thus it seems that caspase- 3 and -7 cooperate in the later phases of apoptosis induction by taxanes via their mutual activation (see Figure 8). Cooperation of caspase-3 and caspase-7 during cell death induction was recently described by Brentnall et al. [41].

\section{Conclusion}

We can summarize that caspase-2 plays the key role of an apical caspase in main death-inducing pathway after taxane application in tested breast cancer cells. This pathway leads from activated caspase- 2 to the activation of executioner caspase- 3 and -7 without the involvement of mitochondria. There is mutual activation of caspase- 3 and -7 . Furthermore, taxanes appear to be able to induce cytochrome c release from mitochondria in some breast cancer cells. In these cases caspase-9 is activated. However, caspase- 9 can also be activated here without the mitochondrial involvement, probably via caspase- 2 activation. This parallel pathway represents another possibility for caspase-3 and caspase-7 activation. It suggests that both pathways can cooperate in cell death induction by taxanes in at least some types of breast cancer cells.

\section{Materials and methods}

\section{Materials}

Paclitaxel was obtained from Sigma-Aldrich (St. Louis, MO, USA). SB-T-1216 was synthesized at the Institute of Chemical Biology and Drug Discovery (Stony Brook, NY, USA). Taxanes were dissolved in DMSO (tissue culture quality) to obtain a $1 \mathrm{mM}$ stock solution.

For western blot analysis, the following primary antibodies were used: mouse monoclonal antibody against caspase-3 (\#9668), rabbit polyclonal antibody against cleaved caspase-3 (\#9661), rabbit polyclonal antibody against caspase-6 (\#9762), rabbit polyclonal antibody against cleaved caspase-6 (\#9761), rabbit polyclonal antibody against caspase-7 (\#9492), rabbit polyclonal antibody against cleaved caspase-7 (\#9491), mouse monoclonal antibody against caspase-8 (\#9746), rabbit monoclonal antibody against cleaved caspase-8 (\#9496), rabbit polyclonal antibody against caspase-9 (\#9502), rabbit polyclonal antibody against cleaved caspase- 9 (\#9505), rabbit polyclonal antibody against COX IV (\#4844), rabbit polyclonal antibody against cytochrome c (\#4272), rabbit polyclonal antibody against PARP (\#9542) from Cell Signaling Technology (Danvers, MA, USA), and mouse monoclonal antibody against actin (AC-40, A3853) from Sigma-Aldrich.

Casp3 Silencer ${ }^{\circ}$ Select Validated siRNA 4427038, Casp7 Silencer ${ }^{\circ}$ Select Validated siRNA 4427038, Casp8 Silencer ${ }^{\circ}$ Select Validated siRNA 4427038, and Casp9
Silencer ${ }^{\circ}$ Select Validated siRNA 4427037 were from Life technologies (Carlsbad, CA, USA).

\section{Cells and culture conditions}

Human breast carcinoma cell lines SK-BR-3 and MCF-7 were obtained from American Type Culture Collection (ATCC, Rockville, MD, USA) and the National Cancer Institute (Frederick, MD, USA), respectively. The cells were maintained in a culture medium at $37^{\circ} \mathrm{C}$ in a humidified atmosphere of $5 \% \mathrm{CO}_{2}$ in air. The culture medium consisted of basic medium supplemented with $10 \%$ heat-inactivated fetal bovine serum (Biochrom AG, Berlin, Germany). The basic medium was RPMI 1640 medium (Sigma-Aldrich, St. Louis, MO, USA) containing extra L-glutamine $(300 \mu \mathrm{g} / \mathrm{ml})$, sodium pyruvate $(110 \mu \mathrm{g} / \mathrm{ml})$, HEPES $(15 \mathrm{mM})$, penicillin $(100 \mathrm{U} / \mathrm{ml})$ and streptomycin $(100 \mu \mathrm{g} / \mathrm{ml})$ [42]. For experiments, paclitaxel and SB-T-1216 were diluted in culture medium to produce a final concentration of $100 \mathrm{nM}$ (SK-BR-3) and $300 \mathrm{nM}$ (MCF-7). These cell death inducing concentrations are the lowest taxane concentrations with nearly maximum effect on tested cells. The concentrations were derived from dose response experiments described in detail previously [20]. DMSO was used as a dissolvent agent for taxanes. DMSO itself at used concentrations was found without any effect on tested cells.

\section{Assessment of cell growth and survival}

Cells were harvested and seeded at $20 \times 10^{3}$ cells $/ 100 \mu \mathrm{l}$ of culture medium into the wells of a 96-well plastic plate. After a 24-h preincubation period allowing cells to attach, the culture medium was replaced by either culture medium without taxane (control) or medium with one of tested taxanes (paclitaxel or SB-T-1216) at desired concentrations. Cell growth and survival were evaluated after $48 \mathrm{~h}$ and $96 \mathrm{~h}$ of incubation. The number of living cells was determined using a hemocytometer after staining with trypan blue.

\section{Preparation of cell lysates}

Cells at desired concentrations were seeded into wells of a plastic plate, Petri dishes or culture flasks and taxanes were applied after a 24-h preincubation. After the incubation period, cells were harvested by low-speed centrifugation $\left(2000 \mathrm{rpm}, 9 \mathrm{~min}, 4^{\circ} \mathrm{C}\right)$, washed in PBS and centrifuged. Cell pellets were stored at $-80^{\circ} \mathrm{C}$. Frozen pellets were resuspended in RIPA buffer (Sigma Aldrich) containing a $1 \%$ mixture of protease inhibitors $\mathrm{P} 8340$ (AEBSF 104 mM, Aprotinin $80 \mu \mathrm{M}$, Bestatin $4 \mathrm{mM}$, E$641.4 \mathrm{mM}$, Leupeptin $2 \mathrm{mM}$, Pepstain A $1.5 \mathrm{mM}$, Sigma Aldrich). Protein lysates were centrifuged $(14,000 \mathrm{rpm}$, $20 \mathrm{~min}, 4^{\circ} \mathrm{C}$ ) and the supernatants containing proteins were stored at $-80^{\circ} \mathrm{C}$. Protein lysates were than analyzed using western blot. 


\section{Cell fractionation}

Cells (approximately $3.6 \times 10^{6}$ cells per sample) were seeded into Petri dishes or culture flasks and taxanes were applied after a $24-\mathrm{h}$ preincubation. After the incubation period, cells were harvested by low-speed centrifugation $\left(2000 \mathrm{rpm}, 9 \mathrm{~min}, 4^{\circ} \mathrm{C}\right)$, washed in PBS and centrifuged again. Cell pellets were resuspended in a specific lysis buffer $\left(75 \mathrm{mM} \mathrm{NaCl}, 1 \mathrm{mM} \mathrm{NaH}{ }_{2} \mathrm{PO}_{4}\right.$, $8 \mathrm{mM} \mathrm{Na}_{2} \mathrm{HPO}_{4}, 250 \mathrm{mM}$ sucrose and $1 \%$ mixture of protease inhibitors P8340 from Sigma Aldrich) containing $0.635 \mathrm{mM}$ digitonin D141 (Sigma-Aldrich) and vortexed for $30 \mathrm{~s}$. Lysates were than centrifuged $\left(14,000 \mathrm{rpm}, 1 \mathrm{~min}, 4^{\circ} \mathrm{C}\right.$ ) and supernatants (cytosolic fractions) were removed and stored at $-80^{\circ} \mathrm{C}$. The specific lysis buffer described above containing $6.35 \mathrm{mM}$ digitonin D141 (Sigma-Aldrich) was added to the pellets and suspensions were vortexed for $30 \mathrm{~s}$ and centrifuged $\left(14,000 \mathrm{rpm}, 1 \mathrm{~min}, 4^{\circ} \mathrm{C}\right)$. After centrifugation, supernatants (mitochondrial fractions) were removed and stored at $-80^{\circ} \mathrm{C}$. Cell fractions were analyzed using western blot.

\section{Western blot analysis}

First, the concentration of proteins in cell lysates was assessed using BCA Protein Assay Reagent from Pierce (Thermo Fisher Scientific, Rockford, IL, USA).

Depending on protein concentration, cell lysates were diluted in RIPA buffer to the gel-loading concentration of proteins $(2.5 \mu \mathrm{g} / \mu \mathrm{l})$, mixed with equal volumes of sample buffer $(0.125 \mathrm{M}$ Tris $/ \mathrm{HCl} \mathrm{pH} 6.8,10 \%$ glycerol, $4 \% \mathrm{SDS}, 0.25 \mathrm{M} \mathrm{DTT}$ ) and heated for $5-7 \mathrm{~min}$ at $110^{\circ} \mathrm{C}$. Protein samples were separated using a protein electrophoresis (Bio-Rad, Hercules, CA). Proteins separated by SDS-PAGE were blotted onto $0.2 \mu \mathrm{m}$ nitrocellulose membrane PROTRAN BA 83 (Whatman-Schleicher and Schuell, Maidstone, UK) for $3 \mathrm{~h}$ at $0.25 \mathrm{~A}$, using a MiniProtean II blotting apparatus (Bio-Rad). The membrane was blocked with $5 \%$ non-fat dry milk or $5 \%$ BSA in TBS for 15-20 min and incubated with the primary antibody at $4^{\circ} \mathrm{C}$ overnight. After the incubation, the membrane was washed three times $(5-10 \mathrm{~min})$ with TBS containing $0.1 \%$ Tween-20. Then it was incubated for $1-2 \mathrm{~h}$ with the corresponding horseradish peroxidaseconjugated secondary antibody (Santa Cruz Biotechnology, Santa Cruz, CA, USA). Afterward, the membrane was washed (as described above) and the chemiluminescence signal was detected using the Supersignal reagents from Pierce (Thermo Fisher Scientific) and a CCD device (Kodak).

\section{RNA interference}

Based on the manufacturer's instructions (INTERFERin ${ }^{\text {th }}$ in vitro siRNA Transfection Protocol, Polyplus transfection $^{\mathrm{Tx}}$ ), RNA interference in SK-BR-3 and MCF-7 cells was completed. The cells were seeded at $2.1 \times 10^{5}$ cells/ $6 \mathrm{ml}$ of culture medium into a Petri dish for a 24-h preincubation. The siRNAs (see "Materials") were diluted in $400 \mu \mathrm{l}$ OPTI-MEM ${ }^{\bullet}$ I Reduced Serum Medium (Gibco, Invitrogen $^{\text {TM }}$ Life Technologies, Carlsbad, CA, USA) to a final concentration of $5 \mathrm{nM}$ and the INTERFERin ${ }^{\text {ma }}$ transfection agent (18 $\mu \mathrm{l}$ per reaction mixture) was added. The mixture was intensively vortexed and incubated for $10 \mathrm{~min}$ at room temperature to form a transfection complex. The preincubation medium in Petri dish was replaced by $4 \mathrm{ml}$ of fresh culture medium. Transfection mixture was added and gently mixed. Cells were incubated in the presence of transfection complexes for $72 \mathrm{~h}$. After incubation, cells were harvested into fresh culture medium and seeded at $2 \times 10^{5}$ cells/ $\mathrm{ml}$ for further analysis. The efficiency of gene silencing using RNA interference was confirmed using western blot analysis followed by densitometry: in the case of SK-BR-3 cells $81 \%$ for caspase-3, 81\% for caspase-7, 94\% for caspase- 8 and $70 \%$ for caspase- 9 , and in the case of MCF-7 cells $81 \%$ for caspase- $7,89 \%$ for caspase- 8 and $61 \%$ for caspase- 9 .

\section{Flow cytometric analysis of the mitochondrial membrane potential $\left(\Delta \psi_{m}\right)$}

Cells (approximately $5 \times 10^{5}$ cells per sample) were seeded into Petri dishes and taxanes were applied after a 24-h preincubation. After the incubation period, cells were harvested by low-speed centrifugation (2000 rpm, $9 \mathrm{~min}, 4^{\circ} \mathrm{C}$ ) and resuspended in PBS. To assess $\Delta \psi_{\mathrm{m}}$,

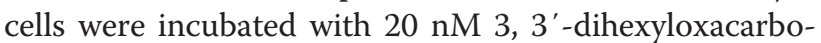
cyanine iodide [DiOC6(3)] from Invitrogen (Grand Island, USA) at $37^{\circ} \mathrm{C}$ for $20 \mathrm{~min}$. As a negative control, the cells were pre-incubated with $100 \mu \mathrm{M}$ carbonyl cyanide m-chlorophenylhydrazone (CCCP) (Sigma-Aldrich, St. Louis, USA), a protonophore causing a complete disruption of the $\Delta \psi_{\mathrm{m}}$, at $37^{\circ} \mathrm{C}$ for $20 \mathrm{~min}$. After incubation, samples were kept on ice. The fluorescence of cells was measured using a FACS Calibur cytometer (Becton Dickinson, San Jose, CA, USA).

\section{Confocal microscopy}

Confocal microscopy was described previously [43]. Briefly, cells were seeded onto coverslips (approximately $2 \times 10^{5}$ cells per coverslip) and taxanes were applied after $24 \mathrm{~h}$ of preincubation. After $36 \mathrm{~h}$ of incubation, cells were stained with Mitotracker Red 480 (Molecular Probes, Grand Island, USA), fixed with $4 \%$ paraformaldehyde at $37^{\circ} \mathrm{C}$ for $15 \mathrm{~min}$ and permeabilized with $0.1 \%$ Triton X-100 in 4\% paraformaldehyde for the next $15 \mathrm{~min}$. After washing with PBS, cells were blocked with Image-iT ${ }^{\mathrm{ma}}$ FX signal enhancer (Molecular Probes, Invitrogen, Eugene, OR, USA) for $30 \mathrm{~min}$. Next, cells were stained with the corresponding primary antibody at $4{ }^{\circ} \mathrm{C}$ 
overnight. Cells were than washed with PBS and incubated with the corresponding secondary antibody for 1 hour in the dark at room temperature. Finally, cells were washed again with PBS. Stained cells on coverslips were transferred onto a droplet of Vectashield ${ }^{\circ}$ Mounting Medium with DAPI (Vector Laboratories, Burlingame, CA, USA) and sealed. Samples were analyzed using a Leica TCS SP5 confocal microscope (Bannockburn, IL, USA) with relevant excitation and emission wavelengths.

\section{Statistical analysis}

Statistical significance of differences was determined using the Student's t-test. $\mathrm{P}<0.05$ and $\mathrm{P}<0.01$ were considered statistically significant at the $5 \%$ and $1 \%$ levels, respectively.

\section{Competing interests}

The authors declare that they have no competing of interests.

\section{Author's contribution}

MJ carried out western blot experiments and worked on the manuscript, KB carried out siRNA techniques and western blot experiments, MS carried out measuring of mitochondrial membrane potential, VNF carried out confocal microscopy and cell fractionation, JŠ participated in cell fractionation, JS participated in western blot experiments, IZ and IO participated in the preparation of SB-T-1216 taxane, JK coordinated the experiments and helped to complete the manuscript. All authors read and approved the final manuscript.

\section{Acknowledgments}

This work was supported by grant 301/09/0362 from the Grant Agency of the Czech Republic (to J.K.); by research project PRVOUK P27 from the Charles University in Prague, and by grant CA 103314 from the National Cancer Institute, USA (to I.O.). The authors thank Mr. Thomas Secrest for English revision.

\section{Author details}

'Department of Cell and Molecular Biology, Third Faculty of Medicine, Charles University, Prague, Czech Republic. ${ }^{2}$ Institute of Chemical Biology and Drug Discovery, State University of New York at Stony Brook, Stony Brook, NY, USA.

\section{Received: 29 January 2014 Accepted: 31 December 2014}

\section{Published online: 04 February 2015}

\section{References}

1. Bedard PL, Di Leo A, Piccart-Gebhart MJ. Taxanes: optimizing adjutant chemotherapy for early-stage breast cancer. Nat Rev Clin Oncol. 2010;7:22-36.

2. Ojima I, Slater JC, Michaud E, Kuduk SD, Bounaud PY, Vrignaud P, et al. Syntheses and structure-activity relationships of the second-generation antitumor taxoids: exceptional activity against drug-resistant cancer cells. J Med Chem. 1996:39:3889-96.

3. Ferlini C, Raspaglio G, Mozzetti S, Cicchillitti L, Filippetti F, Gallo D, et al. The seco-taxane IDN5390 is able to target class III beta-tubulin and to overcome paclitaxel resistance. Cancer Res. 2005;65:2397-405.

4. Galletti E, Magnani M, Renzulli ML, Botta M. Paclitaxel and docetaxel resistance: molecular mechanisms and development of new generation taxanes. Chem Med Chem. 2007;2:920-42.

5. Ehrlichová M, Koc M, Truksa J, Nad’ová Z, Václavíková R, Kovář J. Cell death induced by taxanes in breast cancer cells: cytochrome $C$ is released in resistant but not in sensitive cells. Anticancer Res. 2005;25:4215-24.

6. Ojima I, Chen J, Sun L, Borella CP, Wang T, Miller ML, et al. Design, synthesis, and biological evaluation of new-generation taxoids. J Med Chem. 2008;51:3203-21

7. Orr GA, Verdier-Pinard P, McDaid H, Horwitz SB. Mechanisms of Taxol resistance related to microtubules. Oncogene. 2003;22:7280-95.
8. Xiao H, Verdier-Pinard P, Fernandez-Fuentes N, Burd B, Angeletti R, Fiser A, et al. Insights into the mechanism of microtubule stabilization by Taxol. Proc Natl Acad Sci U S A. 2006;103:10166-73.

9. Yuan SY, Hsu SL, Tsai KJ, Yang CR. Involvement of mitochondrial pathway in Taxol-induced apoptosis of human T24 bladder cancer cells. Urol Res. 2002;30:282-8.

10. Morse DL, Gray H, Payne CM, Gillies RJ. Docetaxel induces cell death through mitotic catastrophe in human breast cancer cells. Mol Cancer Ther. 2005:4:1495-504.

11. Mediavilla-Varela M, Pacheco FJ, Almaguel F, Perez J, Sahakian E, Daniels TR, et al. Docetaxel-induced prostate cancer cell death involves concomitant activation of caspase and lysosomal pathways and is attenuated by LEDGF/ p75. Mol Cancer. 2009;8:68

12. Vobořilová J, Němcová-Fürstová V, Neubauerová J, Ojima I, Zanardi I, Gut I, et al. Cell death induced by novel fluorinated taxanes in drug-sensitive and drug-resistant cancer cells. Invest New Drugs. 2011;29:411-23.

13. Mhaidat NM, Wang Y, Kejda KA, Zhang XD, Hersey P. Docetaxel-induced apoptosis in melanoma cells is dependent on activation of caspase-2. Mol Cancer Ther. 2007;6:752-61.

14. Kovář J, Ehrlichová M, Smejkalová B, Zanardi I, Ojima I, Gut I. Comparison of cell death-inducing effect of novel taxane SB-T-1216 and paclitaxel in breast cancer cells. Anticancer Res. 2009;29:2951-60.

15. von Haefen C, Wieder T, Essmann F, Schulze-Osthoff K, Dörken B, Daniel PT. Paclitaxel-induced apoptosis in BJAB cells proceeds via a death receptorindependent, caspases-3/-8-driven mitochondrial amplification loop. Oncogene. 2003;22:2236-47.

16. Liao PC, Tan SK, Lieu CH, Jung HK. Involvement of endoplasmic reticulum in paclitaxel-induced apoptosis. J Cell Biochem. 2008;104:1509-23.

17. Park SJ, Wu CH, Gordon JD, Zhong X, Emami A, Safa AR. Taxol induces caspase-10-dependent apoptosis. J Biol Chem. 2004;279:51057-67.

18. Zhivotovsky B, Orrenius S. Caspase-2 function in response to DNA damage. Biochem Biophys Res Commun. 2005;331:859-67.

19. Tinel A, Janssens S, Lippens S, Cuenin S, Logette E, Jaccard B, et al. Autoproteolysis of PIDD marks the bifurcation between pro-death caspase-2 and pro-survival NF-kappaB pathway. EMBO J. 2007;26:197-208.

20. Jelínek M, Balušíková K, Kopperová D, Němcová-Fürstová V, Šrámek J, Fiedlerová J, et al. Caspase-2 is involved in cell death induction by taxanes in breast cancer cells. Cancer Cell Int. 2013;13:42.

21. Ho LH, Read SH, Dorstyn L, Lambrusco L, Kumar S. Caspase-2 is required for cell death induced by cytoskeletal disruption. Oncogene. 2008;27:3393-404.

22. Wang YF, Chen CY, Chung SF, Chiou YH, Lo HR. Involvement of oxidative stress and caspase activation in paclitaxel-induced apoptosis of primary effusion lymphoma cells. Cancer Chemother Pharmacol. 2004;54:322-30.

23. Janssen K, Pohlmann S, Jänicke RU, Schulze-Osthoff K, Fischer U. Apaf-1 and caspase-9 deficiency prevents apoptosis in a Bax-controlled pathway and promotes clonogenic survival during paclitaxel treatment. Blood. 2007;110:3662-72.

24. Drago-Ferrante R, Santulli A, Di Fjord R, Giuliano M, Calvaruso G, Tesoriere G, et al. Low doses of paclitaxel potently induce apoptosis in human retinoblastoma Y79 cells by up-regulating E2F1. Int J Oncol. 2008;33:677-87.

25. André N, Carré M, Brasseur G, Pourroy B, Kovacic H, Briand C, et al. Paclitaxel targets mitochondria upstream of caspase activation in intact human neuroblastoma cells. FEBS Lett. 2002;532:256-60.

26. Luo Y, Ling Y, Guo W, Pang J, Liu W, Fang Y, et al. Docetaxel loaded oleic acid-coated hydroxyapatite nanoparticles enhance the docetaxel-induced apoptosis through activation of caspase-2 in androgen independent prostate cancer cells. J Control Release. 2010;147:278-88.

27. Mhaidat NM, Zhang XD, Jiang CC, Hersey P. Docetaxel-induced apoptosis of human melanoma is mediated by activation of c-Jun $\mathrm{NH2}$-terminal kinase and inhibited by the mitogen-activated protein kinase extracellular signalregulated kinase 1/2 pathway. Clin Cancer Res. 2007;13:1308-14.

28. Kim JY, Chung JY, Lee SG, Kim YJ, Park JE, Yoo KS, et al. Nuclear interaction of Smac/DIABLO with Survivin at G2/M arrest prompts docetaxel-induced apoptosis in DU145 prostate cancer cells. Biochem Biophys Res Commun. 2006:350:949-54

29. Chadderton A, Villeneuve DJ, Gluck S, Kirwan-Rhude AF, Gannon BR, Blair $D E$, et al. Role of specific apoptotic pathways in the restoration of paclitaxelinduced apoptosis by valspodar in doxorubicin-resistant MCF-7 breast cancer cells. Breast Cancer Res Treat. 2000;59:231-44.

30. Flores ML, Castilla C, Ávila R, Ruiz-Borrego M, Sáez C, Japón MA. Paclitaxel sensitivity of breast cancer cells requires efficient mitotic arrest and disruption of Bcl-xL/Bak interaction. Breast Cancer Res Treat. 2012;133:917-28. 
31. Sarkar S, Mazumdar A, Dash R, Sarkar D, Fisher PB, Mandal M. ZD6474 enhances paclitaxel antiproliferative and apoptotic effects in breast carcinoma cells. J Cell Physiol. 2011;226:375-84.

32. Friedrich K, Wieder T, Von Haefen C, Radetzki S, Jänicke R, Schulze-Osthoff K, et al. Overexpression of caspase-3 restores sensitivity for drug-induced apoptosis in breast cancer cell lines with acquired drug resistance. Oncogene. 2001;20:2749-60

33. Perchellet EM, Crow KR, Gakhar G, Nguyen TA, Shi A, Hua DH, et al. Bioactivity and molecular targets of novel substituted quinolines in murine and human tumor cell lines in vitro. Int J Oncol. 2010;36:673-88.

34. Li Y, Xing D, Chen Q. Dynamic monitoring of apoptosis in chemotherapies with multiple fluorescence reporters. Mol Imaging Biol. 2009;11:213-22.

35. Yang YI, Lee KT, Park HJ, Kim TJ, Choi YS, Shih IM, et al. Tectorigenin sensitizes paclitaxel-resistant human ovarian cancer cells through downregulation of the Akt and NFkB pathway. Carcinogenesis. 2012;33:2488-98.

36. Ofir R, Seidman R, Rabinski T, Krup M, Yavelsky V, Weinstein Y, et al. Taxol induced apoptosis in human SKOV3 ovarian and MCF7 breast carcinoma cells is caspase-3 and caspase-9 independent. Cell Death Differ. 2002;9:636-42.

37. Mao HL, Liu PS, Zheng JF, Zhang PH, Zhou LG, Xin G, et al. Transfection of Smac/DIABLO sensitizes drug-resistant tumor cells to TRAlL or paclitaxelinduced apoptosis in vitro. Pharmacol Res. 2007;56:483-92.

38. Fabbri F, Amadori D, Carloni S, Brigliadori G, Tesei A, Ulivi P, et al. Mitotic catastrophe and apoptosis induced by docetaxel in hormone-refractory prostate cancer cells. J Cell Physiol. 2008;217:494-501.

39. Almubarak H, Jones A, Chaisuparat R, Zhang M, Meiller TF, Scheper MA. Zoledronic acid directly suppresses cell proliferation and induces apoptosis in highly tumorigenic prostate and breast cancers. J Carcinog. 2011;10:2.

40. Ajabnoor GM, Crook T, Coley HM. Paclitaxel resistance is associated with switch from apoptotic to autophagic cell death in MCF-7 breast cancer cells. Cell Death Dis. 2012;3:260.

41. Brentnall M, Rodriguez-Menocal L, De Guevara RL, Cepero E, Boise LH. Caspase-9, caspase-3 and caspase-7 have distinct roles during intrinsic apoptosis. BMC Cell Biol. 2013;14:32

42. Musílková J, Kovár J. Additive stimulatory effect of extracellular calcium and potassium on non-transferrin ferric iron uptake by HeLa and K562 cells. Biochim Biophys Acta. 2001;1514:117-26.

43. Koc M, Nad'ová Z, Truksa J, Ehrlichová M, Kovár J. Iron deprivation induces apoptosis via mitochondrial changes related to Bax translocation. Apoptosis. 2005:10:381-93.

\section{Submit your next manuscript to BioMed Central and take full advantage of:}

- Convenient online submission

- Thorough peer review

- No space constraints or color figure charges

- Immediate publication on acceptance

- Inclusion in PubMed, CAS, Scopus and Google Scholar

- Research which is freely available for redistribution 